\title{
Três trens
}

Adílson Citelli

Professor livre-docente no Departamento de Comunicações e Artes da ECA-USP e chefe do Departamento de Comunicações e Artes. E-mail: citelli@uol.com.br

Os três números anteriores da revista Comunicação Ẽ Educação propuseram aos leitores acompanhar determinados processos de apropriação intertextual que podem marcar a produção poética. Neste número trataremos de experiência semelhante, porém distinta em seus mecanismos de passagem entre as diferentes discursividades que circundam a arte e a literatura.

Juntamos três poetas cujos textos fazem referência imediata ao trem. Este elemento temático é desdobrado, certamente, sob compreensões múltiplas, ganhando tonalidades distintas que revelam o modo de cada autor trabalhar o material poético. É curioso observar, contudo, como Solano Trindade, Ascenso Ferreira e Manuel Bandeira, os nossos três condutores nesta edição, acentuaram nos poemas transcritos a seguir o movimento que aproxima aos sons do trem os arranjos fônicos e fonéticos ajustados à seqüência dos versos. Ademais, os poemas "Tem Gente com Fome", "Trem das Alagoas" e "Trem de Ferro", exatamente pelo ritmo que apresentam, permitiram a músicos como Ney Matogrosso (Secos e Molhados), Villa Lobos (a se ouvirem os caipiríssimos trenzinhos), Alceu Valença (na composição "Vou me Embora pra Catende") e Antônio Carlos Jobim (no diálogo com Manuel Bandeira) realizarem marcantes transcriações musicais. Ou seja, verificamos, agora, um jogo não apenas intertextual, mas também entre séries discursivas diversas: referentes ao plano verbal (com sua evidente musicalidade) e ao musical (notas, instrumentos, arranjos melódicos, harmonias etc.).

Faremos a seguir uma sumária localização dos poetas, seguida do texto objeto de nosso interesse.

Solano Trindade nasceu no dia 24 de julho de 1908 e morreu no Rio de Janeiro em 19 de fevereiro de 1974. Negro, de origem simples, filho de pai sapateiro, viria a se constituir num dos mais respeitados agitadores culturais brasileiros. Desde 1934, quando participou do I e II Congresso Afro-brasileiro, realizados no Recife e em Salvador, respectivamente, Solano tornar-se-ia um importante nome nas artes e na política do País. Ao mudar-se para o Rio de Janeiro, nos anos 1940, junto com Abdias Nascimento e Haroldo Costa, passou a desenvolver marcante trabalho no teatro, ajudando a criar o Teatro Experimental do Negro. Por sua militância no Partido Comunista Brasileiro, foi preso em 1945 durante a repressão desencadeada pelo governo Dutra. Em 1967 mudou-se para a cidade do Embu, próxima de São Paulo, transformando-a num pólo cultural da arte brasileira. Foi ator, poeta e liderança no movimento negro. 
O grupo musical Secos \& Molhados e Ney Matogrosso musicaram o texto de Solano Trindade.

\section{TEM GENTE COM FOME'}

Trem sujo da Leopoldina, correndo, correndo, parece dizer: tem gente com fome, tem gente com fome, tem gente com fome...

\section{Piiiii}

Estação de Caxias, de novo a correr, de novo a dizer:

tem gente com fome, tem gente com fome, tem gente com fome...

Vigário Geral

Lucas, Cordovil

Brás de Pina

Penha Circular

Estação da Penha

Olaria, Ramos

Bom Sucesso

Carlos Chagas

Triagem, Mauá.

Trem sujo da Leopoldina, correndo, correndo, parece dizer:

tem gente com fome, tem gente com fome, tem gente com fome...

Ascenso Carneiro Gonçalves Ferreira nasceu em Palmares, Pernambuco, em 1895. Esteve entre os agitadores da Semana de Arte Moderna de 1922. Morreu no Recife em 5 de maio de 1965. Dotado de veia irônica, o poeta escreveu um dos textos mais satíricos da literatura brasileira, o poema "Filosofia": "Hora de comer - comer!/ Hora de dormir - dormir!/ Hora de vadiar - vadiar!/ Hora de trabalhar? - Pernas pro ar que ninguém é de ferro!".

O poema "Trem das Alagoas" recebeu tratamento musical de Villa Lobos e Alceu Valença. 


\section{TREM DAS ALAGOAS²}

O sino bate,

o condutor apita o apito,

Solta o trem de ferro um grito,

põe-se logo a caminhar...

- Vou danado pra Catende,

vou danado pra Catende,

vou danado pra Catende

com vontade de chegar...

Mergulham mocambos,

nos mangues molhados,

moleques, mulatos,

vêm vê-lo passar.

- Adeus!

- Adeus!

Mangueiras, coqueiros,

cajueiros em flor,

cajueiros com frutos

já bons de chupar...

- Adeus morena do cabelo cacheado!

Mangabas maduras, mamões amarelos, mamões amarelos, que amostram molengos

as mamas macias

pra a gente mamar

- Vou danado pra Catende, vou danado pra Catende, vou danado pra Catende com vontade de chegar...

Na boca da mata há furnas incríveis que em coisas terríveis nos fazem pensar:
- Ali dorme o Pai-da-Mata!

- Ali é a casa das caiporas!

- Vou danado pra Catende, vou danado pra Catende, vou danado pra Catende com vontade de chegar...

Meu Deus! Já deixamos a praia tão longe...

No entanto avistamos

bem perto outro mar...

Danou-se! Se move, se arqueia, faz onda... Que nada! É um partido já bom de cortar...

- Vou danado pra Catende, vou danado pra Catende, vou danado pra Catende com vontade de chegar...

Cana caiana,

cana roxa,

cana fita, cada qual a mais bonita, todas boas de chupar...

- Adeus morena do cabelo cacheado!

- Ali dorme o Pai-da-Mata!

- Ali é a casa das caiporas!

- Vou danado pra Catende, vou danado pra Catende, vou danado pra Catende com vontade de chegar

Manuel Carneiro de Souza Bandeira Filho nasceu no Recife, em 19 de abril de 1886, e morreu no Rio de Janeiro, em 13 de outubro de 1968. Em 1903, em São Paulo, iniciou o curso superior na Escola Politécnica, com o propósito

2. FERREIRA, Ascenso Carneiro Gonçalves. Cana-caiana. Rio de Janeiro: José Olympio, 1939. p. 65. 


\begin{abstract}
de se tornar arquiteto. Um ano depois, com diagnóstico de tuberculose, vai para o Rio de Janeiro e, tempos depois, busca tratamento na Suíça. Com a eclosão da guerra de 1914, volta ao Brasil. Passa a se corresponder com Mário de Andrade e liga-se aos modernistas: o seu poema "Os Sapos" foi lido por Ronald de Carvalho na célebre semana de 1922, ocorrida no Teatro Municipal. Em 1924 publica seu primeiro livro, Poesias, seguido de $O$ ritmo dissoluto. Em anos posteriores, produz uma série de livros que farão de Bandeira um dos maiores nomes da poesia brasileira. Seu poema "Trem de Ferro" foi musicado por Antônio Carlos Jobim.
\end{abstract}

\title{
TREM DE FERRO ${ }^{3}$
}

Café com pão

Café com pão

Café com pão

Virge Maria que foi isto maquinista?

Agora sim

Café com pão

Agora sim

Café com pão

Voa, fumaça

Corre, cerca

Ai seu foguista

Bota fogo

$\mathrm{Na}$ fornalha

Que eu preciso

Muita força

Muita força

Muita força

(trem de ferro, trem de ferro)

Oô...

Foge, bicho

Foge, povo

Passa ponte

Passa poste

Passa pasto

Passa boi

Passa boiada

Passa galho

Da ingazeira
Debruçada

No riacho

Que vontade

De cantar!

Oô...

(café com pão é muito bom)

Quando me prendero

No canaviá

Cada pé de cana

Era um oficiá

Oô...

Menina bonita

Do vestido verde

Me dá tua boca

Pra matá minha sede

Oô...

Vou mimbora vou mimbora

Não gosto daqui

Nasci no sertão

Sou de Ouricuri

Oô...

Vou depressa

Vou correndo

Vou na toda

Que só levo

Pouca gente

Pouca gente

Pouca gente...

(trem de ferro, trem de ferro). 